Author: LTC Harms

LAW AND LANGUAGE IN A MULTILINGUAL SOCIETY

ISSN 1727-3781

2012 VOLUME 15 No 2

http://dx.doi.org/10.4314/peli.v15i2.2 


\section{Law and Language in a Multilingual Society}

LTC Harms*

Terence McKenna, in Wild Ducks Flying Backwards, said that he did not believe that the world is made of quarks or electro-magnetic waves, or stars, or planets, or of any such things. 'I believe' he said, 'the world is made of language.' It would have been more correct to have said that the world is made of languages, many of them.

The subject, Law and Language in a Multilingual Society, raises critical issues not only for us in this country but also for others because language is part - the greater part - of one's culture. A people without a culture is said to be like a zebra without stripes. Culture, and not race, nationality, religion or border (natural or political), determines one's identity. As one of the founding fathers of the Afrikaans language, Rev SJ du Toit, wrote in 1891: language is a portrait of the soul and life of a nation; and it mirrors the character and intellectual development of a people (my translation).

Unfortunately language tends to divide, more particularly, a multilingual society. Law is supposed to close the divide but more often than not widens it and is used to deepen divisions. This is because the ruler determines the law and, consequently, the language of the law, in the belief that the use of language can be enforced from above. Law and language, like oil and water, do not mix although the former is dependent on the latter.

The reason this paper is in English may have had its origin in an incident at the Pretoria Bar, of which I had been a member. During 1910 the Bar held a dinner for the appointees to the newly formed Appellate Division, including a future Chief Justice, Sir James Rose-Innes. It was attended by Sir Patrick Duncan, a future

Judge Louis Harms, paper is based on a paper read at the 12th International Conference of the International Academy of Linguistic Law, 1 November 2010, Bloemfontein. LTC Harms, Former Deputy President, Supreme Court of Appeal Professor: Adams \& Adams Chair in Intellectual Property Law, University of Pretoria 29 May 2012 louis.harms@gmail.com 
Governor-General. The speech was made by NJ de Wet, who later also became a Chief Justice and was to act as Governor-General during Sir Patrick's illness. But he spoke Dutch. This annoyed some, particularly Sir Patrick, who felt that it was inappropriate considering that part of the audience was not fully conversant with Dutch. Since then, but not because of this, Afrikaans speakers have been very sensitive about the choice of language and have tended to please those who might not understand their language. Proof of this conciliatory approach is to be found in the fact that General Hertzog, when prime minister, chose Sir Patrick to be Governor-General (not that the latter reciprocated when he refused to follow convention and disband parliament at the request of Hertzog, but that is another matter). Another instance is when counsel in the Supreme Court of Appeal responded in English to a question put to him in Afrikaans on the assumption that because of the judge's race he would understand English better. He rephrased his answer in Afrikaans after the judge had asked him if he had misunderstood the question.

What follows will be the result of a knee-jerk reaction, some experience and a smattering of emotion, and will be personal. Some observations will be historical and legalistic, and the rest anecdotal.

Many South Africans who descend from 'European colonialists' suffer amomg other thngs from cultural schizophrenia and have an identity crisis. In my instance my father tongue and home language was German, my mother tongue English, and Afrikaans is now my home language. It is not possible in those circumstances to be a language chauvinist.

After the Norman conquest of Britain the court language and the language of the law became Norman-French. It was only after the Normans became anglicized and the people homogenized that English (no longer Anglo-Saxon) became the language of the law.

Likewise, after the rise of Afrikaner nationalism Afrikaans became an important legal 
language. This occurred in spite of the fact that Afrikaans is not a 'White' language or a language of Whites. It is a language that does not and never did belong to a particular racial group. But since the demise of Afrikaner nationalism Afrikaans as a language of law is in retreat.

Namibia provides an interesting case. Afrikaans was generally spoken and understood by all in South-West Africa. English was used by but a small group of persons, primarily as a second or third language. Upon independence Afrikaans, perceived as the language of the vanquished conqueror, was replaced with English as the only official language.

This says something about Africa. It presents a strange phenomenon. Although Africa is usually regarded as uniform it is not because it is divided for international political reasons into Arabic, English, French, Portuguese and Spanish speaking countries. This division is symbolic of Africa: it is a divided Continent and its official languages and legal systems are by and large those of its erstwhile colonial masters and not those of its people.

One would, with the rise of African nationalism and the search for an African Renaissance, have expected that Africa would have sought to give preference to its own languages. But that has not happened, not even in the odd monolingual African country. The colonial language became the language of the elite, and it is used to reserve privileges for the new elite - quite like the position in Britain after the Norman invasion. As Mosibudi Mangena has said (Sunday Times of 15 August 2010):

The language of debate in parliament and of doing state business must be colonial, and the fact that the majority of the people understand neither the language nor the colonial way of conducting business does not matter. . . . The languages of the colonisers ... are a mark of success, class, civilisation and a vehicle to access resources.

I do not know of any university South of the Sahara that teaches law in a local language. Court language, at least in the higher courts, is invariably European. The result is that African languages have failed to develop a modern scientific legal 
vocabulary.

The one exception is Afrikaans, one of three major languages that developed during the 20th Century. Afrikaans was able to create a legal language of its own because of its close relationship to Dutch and German in particular and because the common law of the country is by a quirk of history Roman-Dutch and not English.

It might be argued, because we have had eleven official languages since 1994 because of provisions of the interim Constitution, that this picture of the language of the law in Africa is skewed, if not untrue, at least as far as South Africa is concerned.

The constitutional provisions about language are often hailed as something wonderful, but that is only because they have had a good press agent. They are the result of political compromise. Compromises seldom satisfy. Unrealistic compromises fail.

South Africa, as a political entity, is a century old. It was a consequence of the AngloBoer War. Another and earlier consequence of the war was the Milner language policy: the language of the country had to be English in spite of the fact that the official language of the Transvaal and the Orange Free State had been Dutch and the unofficial language embryonic Afrikaans. The policy did not succeed. Maybe it is a pity that it did not.

The Union of South Africa was created on 31 May 1910. Its Constitution, locally devised but an Act of the Westminster Parliament, had a language provision in terms of which the official languages of the country were to be English and Dutch, each with an equal standing. Afrikaans, as a language, had not yet been formalized and was not recognised. The African languages, like the rights of the indigenous peoples, did not feature.

Afrikaans grew and during 1925 the Constitution was amended to equate Afrikaans with Dutch. In other words, Afrikaans was introduced as an alternative to Dutch and very soon Afrikaans replaced Dutch in practical terms. 
Statutes were always published in both languages. They were signed in either the one or the other although the two texts, both of which had to be approved by Parliament, had equal status. In the event of an irreconcilable conflict the signed text took precedence.

Published judgments of the higher courts and the Appellate Division did not reflect the intention of the 1910 Constitution. There are no reported judgments in Dutch. A few inconsequential Afrikaans judgments were delivered in that court after the 1930s. Except for judgments by the likes of Van den Heever J, who was also a poet, there were prior to 1947 hardly any published higher court judgments in Afrikaans. Judge Neville Holmes was proud of the fact that he had delivered the first high court judgment in Afrikaans in Natal; it was during 1958 (half a century after unification). Even in the randomly selected 1948 (2) SA Law Reports, 3 pages (one judgment) are in Afrikaans and 1293 pages in English.

A case between what was then an Afrikaans university, the University of Pretoria, and the Minister of Education, Mr Jan Hofmeyr, who was Afrikaans, was argued in 1947. Counsel for the University, Oswald Pirow and Frans Rumpff (the former had been a Minister of Justice and the latter became Chief Justice) argued in Afrikaans. Counsel for the Minister, although conversant in Afrikaans, argued in English. The University lost. The judgment by Malan J was in English. He was Afrikaans-speaking. (University of Pretoria v Minister of Education 1948 (1) SA 411, 1948 (4) SA 79) (T).)

Things changed during the late 1950s. Many judges adopted a rule of thumb. Judgments were to be in the language of the parties. If their language differed, the judgment was in the language of the loser on the basis that a winner is satisfied with the result and has less interest in the reasoning. This did not apply to indigenous languages because they had no legal status. If someone spoke in one of them the proceedings were interpreted from and into one of the official languages.

At the time it was statutorily required that someone who applied to be admitted as an advocate had to have completed university courses in Afrikaans, English and Latin. 
Matters were different, however, after the 1970s, in the so-called independent homelands. These chose their own language (isiXhosa for Transkei for instance) and English as their official languages. Although they published their laws in their chosen indigenous language in addition to English, no one bothered to have regard to the former and, in particular, all court proceedings were conducted in English.

Then came the 'constitutional' era with its 11 languages. The first victim (some would say 'triumph') of the language clause was the Latin requirement for advocates, which was abolished in 1994. And the abolition of all language requirements for advocates followed in 1995. Universities now have a free hand in determining their degree requirements. Lawyers without language qualifications? I thought, apparently wrongly, that language is the lawyer's tool.

The re-incorporation of the homelands into mainstream South Africa also had its effect. Judicial officers and practitioners from those areas did not know Afrikaans and were unable to conduct cases in that language.

Statutes are now prepared in one language only and pass Parliament in that language. It is the official text. The language is English, often as she is not usually spoken. As a sop to the Constitution, each statute is translated into one of the other ten languages but the translation has no value because it has no official status. The translations are not even published by commercial law publishers, and since nine of the languages do not have their own legal terminology, the task to translate is enormous, wasteful and unnecessary. This course of action, prescribed by the Constitution,could hardly been seen as a rational choice when one takes into account usage, practicality, and expense.

Courts, too, pay lip service to the equality of the eleven official languages. The Black languages retained their status as second-class languages, ie, languages that have to be translated or interpreted into English or (to a limited extent) Afrikaans, save for a small-scale experiment that is being conducted by the Department of Justice. The court languages, accordingly, remained English and Afrikaans, save for the fact that Afrikaans is losing ground rapidly, something compouned by the fact that a 
substantial number of judges are rabidly against the use of Afrikaans as a court language.

The rules of the Constitutional Court have two language provisions. The first is that if any document is not in an official language 'understood by all the judges' it has to be translated into that language. The only language understood by all is English. The second is that counsel may argue in any official language but if the oral argument is to be in a language other than that of the brief, notice has to be given, presumably in order to find an interpreter. One judge only, long since retired, has on rare occasions written a judgment in Afrikaans. No judgment has been written in any other official language save in English.

Importantly, the judgments are not translated into the language of the parties or into a second official language. Canada's 'bi-juralism' as practised in the Supreme Court ought to have served as example.

There is a knock-on effect. Judges who are conversant with Afrikaans are presented with a dilemma. If they write in Afrikaans the judgment would have no precedential value because not all students, lawyers or judges would be able to read or understand it. The Constitutional Court would have had to judge a translated judgment - a translation that the particular judge would not have seen and would not know whether or not it was correct. The result of all this is that the practice has arisen that judgments are to be in English unless the author is comfortable in Afrikaans, the parties and proceedings are in Afrikaans, and the case has no precedential value.

The question arises immediately how all of this is compatible with the Constitution. The answer is that, although the Constitution declared eleven languages to be official languages, it did not give those equal rights or guarantee them equal protection. All it does is to state that all official languages must enjoy parity of esteem and must be treated equitably. This creates nothing more than something akin to a natural obligation in Roman and civil law where the obligation flows from the conscience of the debtor: 'Le véritable base de l'obligation est toujours dans la 
conscience des contractants.'

In any event, the provision is subject to an overriding proviso:

The national government and provincial governments may use any particular official languages for the purposes of government, taking into account usage, practicality, expense, regional circumstances and the balance of the needs and preferences of the population as a whole or in the province concerned; but the national government and each provincial government must use at least two official languages.

The problem with the proviso is that it is open to political abuse. The choice of languages, if limited to two, will inevitably lead to the dominance of English and the rejection of Afrikaans and other relevant languages, irrespective of their prevalence in any geographical area. By the way, it would appear that the Constitution does not regard Afrikaans as 'indigenous', a term reserved for languages that had a diminished status before 1994.

Then there is sub-section 6(4) of the Constitution. It requires of the national and provincial governments to regulate and monitor their use of official languages. As was held by Du Plessis $J$ in Lourens $v$ Die President [2010] ZAGPPHC 19, Government has failed to comply with this constitutional duty. It does not appear from the judgment that Government was able to explain its lackadaisical approach. It probably assumed that if the problem was ignored it would disappear.

A similarly toothless provision in the Bill of Rights relates to education. Everyone has the right to receive education in the official language or languages of their choice in public educational institutions. However, it must be reasonably practicable. And every decision must take into account (a) equity; (b) practicability; and (c) the need to redress the results of past racially discriminatory laws and practices.

The fact that one has the right to use one's language of choice is also meaningless if the court cannot understand that language or if what is said or written therein is 
ignored. Few Black accused are tried in a language they understand and this now also applies to Afrikaans-speaking accused. Translated evidence remains suspect.

The huge legal academic contribution in Afrikaans has become as inaccessible as Latin texts have become. One sees this in the contributions to law journals. The first and foremost Afrikaans law journal, Tydskrif vir Hedendaagse Romeins-Hollandse Reg, was established in 1938. The contributions were nearly exclusively in Dutch and Afrikaans. Today, in spite of its object of nurturing the Afrikaans legal language, contributions in Afrikaans fell from 39 per cent in 2005 to 12 per cent in 2010. The others are in English. This trend is as strong if not stronger in other disciplines.

In other words, as George Orwell would have said, 'all languages are equal but English is more equal than others.' The simple fact is that languages in a multicultural society are not equal.

One may agree with Stephen Jay Gould that English has become the lingua franca, of scientific discourse (The Hedgehog, the Fox and the Magister's Pox). In this regard it occupies the position of Latin until the beginning of the 19th Century. By the way, the Department of Justice, historically and linguistically challenged, refers to Roman script on its website as English script.

What has been said thus far may have sounded as a call for special recognition of Afrikaans. That is not the intention. Afrikaans is simply used by way of illustration. African languages are in a far worse position. They are simply ignored.

The English author, GK Chesterton, wrote a futuristic novel, The Napoleon of Notting Hill, at the beginning of the 20th Century. It was set at the beginning of this century. It includes a story about the President of Nicaragua, whose country had disappeared through the 'brute powers of modernity'. There were only a few mega-countries left, Britain being the foremost. The President, lonely in London, was lamenting the loss of his country. The Englishman to whom he spoke explained that the loss was inevitable. He said: 
We do not discourage small nationalities because we wish large nationalities to have all their smallness, all their uniformity of outlook, all their exaggeration of spirit. If I differ with the greatest respect from your Nicaraguan enthusiasm . . . it is because civilization was against you. We moderns believe in a great cosmopolitan civilization ....

Chesterton might have been wrong on the future greatness of Britain. But he was right with the last sentence, which identifies the problem: the 'great cosmopolitan civilization'; Disneyland culture; cultural colonialism; the global village; and Google gobbling. Even a recent French entry at the Eurosong competition was sung in English. The world will soon be divided between Mandarin and English.

The role of the law in protecting or promoting language is limited. A love for culture cannot be imposed. Culture comes from the heart, from the gut. If Afrikaans is becoming irrelevant it is not because of the law only - it is because the Afrikaansspeaking population is losing heart or losing its heart. To illustrate: Some years ago a new law library was opened at a former Afrikaans university. All of the speakers, from the Principal to the Dean were Afrikaans. They spoke English. The only speaker who used Afrikaans was Mr Mbeki, then the President. He hardly qualifies as Afrikaans.

The poet NP van Wyk Louw wrote in 1959: 'Dit wat ons taal sal word, of oor wat van hom sal word, kan ons nie praat nie - behalwe met hartstogtelike verlange' (Van Wyk Louw, 'Laat ons nie roem nie,' in Versamelde Prosa II p 181). (We cannot speak about what our language will become; and we cannot speak about what will become of our language - except with a passionate yearning. My translation.)

In this I have stated problems and have not given any answers, simply because I do not have any unless, on a lighter note, we adopt a script similar to Sinograms (or Han characters) for legal purposes. They can be used by a plurality of languages because they represent words and not any particular language or sound.

\section{LTC Harms}

Former Deputy President, Supreme Court of Appeal 
Professor: Adams \& Adams Chair in Intellectual Property Law, University of Pretoria 29 May 2012 